\title{
Implementation Of Genetic Algorithm In Optimization Of Subject Scheduling
}

\author{
Listanto Tri Utomo ${ }^{\mathrm{a}, 1}$, Farid Wahyudi ${ }^{\mathrm{b}, 2}$ \\ a Informatics Engineering Study Program, Faculty of Science and Technology, Raden Rahmat Islamic University of \\ Malang, Indonesia \\ b Information System Study Program, Faculty of Science and Technology, Raden Rahmat Islamic University of Malang, \\ Indonesia \\ ${ }^{1}$ listantotri@gmail.com; ${ }^{2}$ faridstifler@gmail.com
}

\begin{tabular}{ll}
\multicolumn{1}{c}{ ABSTRAC T } \\
$\begin{array}{ll}\text { Keywords } \\
\text { Scheduling }\end{array}$ & $\begin{array}{l}\text { The activity of implementing teacher teaching schedules in a school is complicated. There } \\
\text { are various aspects related to the scheduling that must be involved, among others there are } \\
\text { schedules in which the teacher intersects with other class schedules, and the distribution } \\
\text { Optimal } \\
\text { of the Teaching and Learning Activities, schedule is also expected to be evenly distributed } \\
\text { each day for each class. Therefore in this study, an application will be made that can } \\
\text { facilitate the preparation of subject schedules automatically by implementing genetic } \\
\text { algorithms. By making an application for preparing the schedule of subjects it is expected } \\
\text { to facilitate and accelerate the student field in the process of making the schedule of } \\
\text { subjects by existing resources and limitations. With this application, it is also expected to } \\
\text { facilitate communication between teachers and students in arranging class schedules so } \\
\text { that they can achieve optimal results at State Vocational High School 1 Malang. }\end{array}$
\end{tabular}

\section{Introduction}

\subsection{Background}

During this time the scheduling of teaching teachers at State Vocational High School 1 Malang which includes subject schedules and the distribution of teachers in each class there is still using the manual method. There are a lot of clashes between classes because of the confusion of the student division to determine the schedule of subjects and the large number of rooms to be adjusted based on grade levels. The problems faced in the Vocational School are the scheduling system which is still manual because it is very complicated and the number of rooms divided for one class, so we need a system that can help the student in determining the schedule of subjects for one school year which is formed automatically through a computerized system.

Therefore in this thesis will try to make an application that can facilitate the preparation of subject schedules automatically by implementing genetic algorithms.

By making an application for preparing the schedule of subjects it is expected to facilitate and accelerate the student field in the process of making the schedule of subjects by existing resources and limitations. With this application, it is also expected to facilitate communication between teachers and students in arranging class schedules so that they can achieve optimal results at State Vocational High School 1 Malang..

\subsection{Formulation of the problem}

1. How do you analyze scheduling problems that occur at State Vocational High School 1 Malang? 
2. How to define the problem in individual form?

3. How to calculate the fitness value of each individual?

4. How to implement Genetic Algorithms into the Java programming language?

5. How to test system performance?

\subsection{Scope of the problem}

1. Desktop-based programs are made with the Java programming language and use a MySQL database.

2. Each teacher has been assigned according to their respective fields of study.

3. Conditions for each individual who has a high fitness value so that the individual is not affected by mutations and crossovers can be seen below:

a. Every teaching and learning activity must not be a time-out on the same subject in 1 day.

b. Maximum teaching and learning activities in 1 subject must not exceed 3 hours in 1 day.

c. On the same day there may not be teaching and learning activities with the same subjects and the same hours in 1 day in different classes.

\subsection{Research purposes}

The purpose of the research to be carried out is to arrange scheduling using genetic algorithms so that an automatic schedule is obtained for the pair of subjects, time, space and the teacher (teacher) as a whole.

\section{The Proposed Method}

\subsection{Scheduling Optimization}

Optimizing subject scheduling is the process of preparing an implementation schedule that informs some subjects, the teaching teacher, the space, and the time of teaching and learning activities can produce an optimal schedule. Manually scheduling tends to require more time and accuracy for schedulers. To be able to make an optimal schedule, optimization methods are needed..

\subsection{Genetic Algorithm}

The template is used to format your paper and style the text. All margins, column widths, line spaces, and text fonts are prescribed; please do not alter them. You may note peculiarities. For example, the head margin in this template measures proportionately more than is customary. This measurement and others are deliberate, using specifications that anticipate your paper as one part of the entire Genetic algorithms are heuristic search techniques based on the idea of the evolution of natural and genetic selection. This algorithm makes use of the natural selection process known as the evolution process.

Here are some basic notions that need to be known:

1. Genes are the basic variables that make up a chromosome. In genetic algorithms, these genes can have binary, float, integer, or character values.

2. Alleles are values of a gene, can be binary, float, integer, or character.

3. A chromosome is a combination of genes that make a certain meaning.

Genetic algorithm consists of eight components, whose task is to support the optimization, while the components are, coding scheme, fitness value, parental selection, crossing, mutation, elitism, population replacement, and cessation criteria. 


\section{Analysis and System planning}

\subsection{Problem Analysis}

From the results of the research carried out it is known that the scheduling process at SMK Negeri 1 Malang is still done manually. So the results obtained are less effective and efficient because it requires a relatively long time.

\subsection{Design of Genetic Algorithms}

\subsubsection{Encoding}

Assignments is done outside the system. The system is only intended to arrange the schedule of The coding that will be used in this subject scheduling application is the value coding.

\subsubsection{Chromosome Initialization}

After this thesis, an individual has one chromosome, and chromosomes are composed of several genes. The length of a chromosome is as much as a gene that represents one day, in this case, each gene represents one subject.

Table 1. Number of Hours Each Weekly Subject

\begin{tabular}{llcc}
\hline Kode & \multicolumn{1}{c}{ Subject } & $\begin{array}{c}\text { Number of Hours } \\
\text { per Week }\end{array}$ & Number of genes \\
\hline MP01 & Pendidikan Agama & 2 & 2 \\
\hline MP02 & PPKn & 2 & 2 \\
\hline MP03 & Bahasa Indonesia & 4 & 4 \\
\hline MP04 & Bahasa Inggris & 6 & 6 \\
\hline MP05 & Matematika & 8 & 8 \\
\hline MP06 & IPA & 6 & 6 \\
\hline MP07 & IPS & 6 & 6 \\
\hline MP08 & Seni budaya & 2 & 2 \\
\hline MP09 & Pejaskes & 2 & 2 \\
\hline MP10 & TIK dasn PTD & 4 & 2 \\
\hline MP11 & Bahasa Daerah & 2 & 2 \\
\hline MP12 & Speaking atau Conversation & 2 & $\mathbf{4 6 ~ G e n}$ \\
\hline \multicolumn{1}{c}{ Total } & 46 Jam & \\
\hline
\end{tabular}

Table 2. Chromosome Initialization

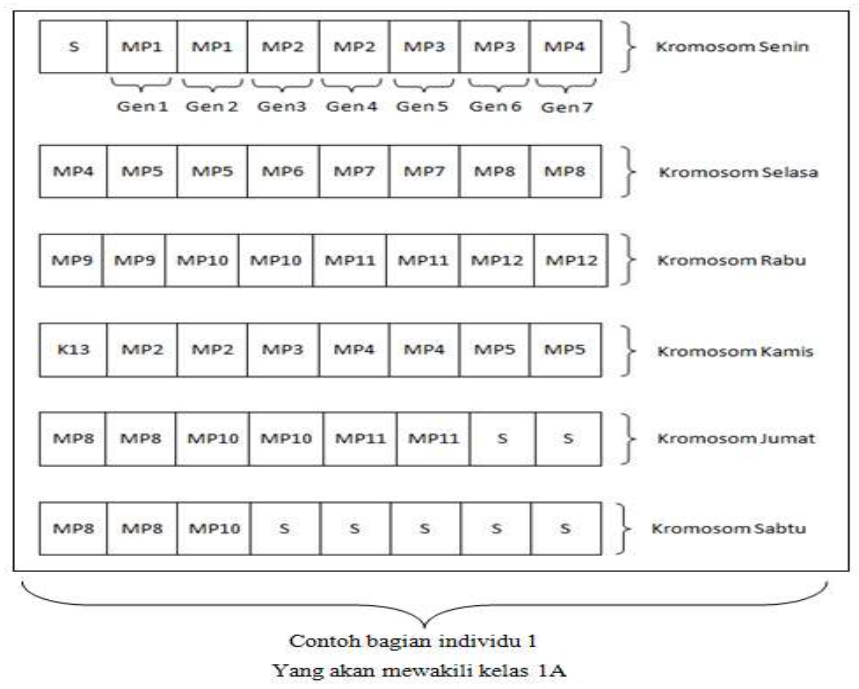

127 | P a g e 
Note: Table 3.4 is an example of a part of individual 1 which is 1 schedule that has been arranged to represent 1 class, namely class $1 \mathrm{~A}$. What is meant by individuals here is 1 whole schedule composed of all class 1 which is formed from 10 classes.

\subsubsection{Calculation of Fitness Values}

Because the value of fitness is closely related to the condition of the value of a gene in a chromosome, then to determine it first seen whether the requirements are met or not. If fulfilled, the greater the weight value by predetermined weights. If it is not met, then the weight value is equal to 0 . More details will be illustrated in the picture below:

1. Requirement 1: Every teaching and learning activity must not have time breaks on the same subject in 1 day.

Table 3. Example illustration of conditions 1

\begin{tabular}{|c|c|c|c|}
\hline Monday & Weight 1 & Information & \\
\hline $\mathrm{S}$ & - & Flag Ceremony & \\
\hline MP1 & 0 & $\begin{array}{l}\text { Fitness value is } 0 \text { because there is MP1 in this } \\
\text { chromosome which emerges pause in the form of } \\
\text { MP2 and MP3 }\end{array}$ & \multirow{7}{*}{$\begin{array}{l}\text { Small weight } \\
\text { value due to } \\
\text { diferent hours } \\
\text { there are } \\
\text { pauses and } \\
\text { there are the } \\
\text { same subjects }\end{array}$} \\
\hline MP1 & 0 & $\begin{array}{l}\text { Fitness value is } 0 \text { because there is MP1 in this } \\
\text { chromosome which emerges pause in the form of } \\
\text { MP2 and MP3 }\end{array}$ & \\
\hline MP2 & 30 & $\begin{array}{l}\text { Fitness value is } 30 \text { because although there are } \\
\text { other MP2 they appear together and there are no } \\
\text { breaks }\end{array}$ & \\
\hline MP2 & 30 & $\begin{array}{l}\text { Fitness value is } 30 \text { because although there are } \\
\text { other MP } 2 \text { they appear together and there are no } \\
\text { breaks }\end{array}$ & \\
\hline MP3 & 30 & $\begin{array}{l}\text { Fitness value } 30 \text { because stand-alone MP } 3 \text { is not } \\
\text { subject to conditions }\end{array}$ & \\
\hline MP1 & 0 & $\begin{array}{l}\text { Fitness value is } 0 \text { because there is MP1 in this } \\
\text { chromosome which emerges pause in the form of } \\
\text { MP2 and MP3 }\end{array}$ & \\
\hline MP6 & 30 & $\begin{array}{l}\text { Fitness value of } 30 \text { because the MP6 stands alone } \\
\text { is not subject to conditions }\end{array}$ & \\
\hline
\end{tabular}

2. Requirement 2: Maximum teaching and learning activities in 1 subject must not exceed 3 hours in 1 day.

Table 4. Example illustration of conditions 2

\begin{tabular}{|c|c|c|}
\hline Monday & Weight 1 & Information \\
\hline MP5 & 30 & $\begin{array}{l}\text { Fitness value } 0 \text { because MP5 stands alone is not } \\
\text { subject to conditions }\end{array}$ \\
\hline MP1 & 0 & $\begin{array}{l}\text { Fitness value is } 0 \text { because there is MP } 1 \text { in this } \\
\text { chromeosome which appears } 4 \text { times and violates } \\
\text { the conditions in } 1 \text { choromosome must have max } \\
3 \text { genes in common }\end{array}$ \\
\hline MP1 & 0 & $\begin{array}{l}\text { Fitness value is } 0 \text { because there is MP } 1 \text { in this } \\
\text { chromeosome which appears } 4 \text { times and violates } \\
\text { the condition in } 1 \text { chromosome must have max } 3 \\
\text { genes in common }\end{array}$ \\
\hline MP1 & 0 & $\begin{array}{l}\text { Fitness value is } 0 \text { because there is MP1 in this } \\
\text { chromeosome which appears } 4 \text { times and violates } \\
\text { the conditions in } 1 \text { choromosome must have max } \\
3 \text { genes in common }\end{array}$ \\
\hline MP1 & 0 & $\begin{array}{l}\text { Fitness value is } 0 \text { because there is MP1 in this } \\
\text { chromeosome which appears } 4 \text { times and violates } \\
\text { the conditions in } 1 \text { choromosome must have max } \\
3 \text { genes in common }\end{array}$ \\
\hline
\end{tabular}

128 I P a g e 


\begin{tabular}{ccl}
\hline Monday & Weight 1 & \multicolumn{1}{c}{ Information } \\
\hline MP3 & 30 & $\begin{array}{l}\text { Fitness value 30 because stand-alone MP3 is not } \\
\text { subject to conditions }\end{array}$ \\
\hline MP4 & 30 & $\begin{array}{l}\text { Fitness value of 30 because MP4 stands with } \\
\text { other MP4 but together }\end{array}$ \\
\hline MP4 & 30 & $\begin{array}{l}\text { Fitness value of 30 because MP4 stands with } \\
\text { other MP4 but together }\end{array}$ \\
\hline
\end{tabular}

3. Requirement 3: On the same day no teaching and learning activities with the same subjects and at the same time in 1 day in different classes.

Table 5. Example illustration of conditions 3

\begin{tabular}{ccccl}
\hline Monday A & Weight 3 & Weight 3 & Monday B & \multicolumn{1}{c}{ Information } \\
\hline S & - & - & S & - \\
\hline MP1 & 30 & 30 & MP3 & $\begin{array}{l}\text { Fitness value 30 because MP1 stands alone is not } \\
\text { subject to condition }\end{array}$ \\
\hline MP1 & 30 & 30 & MP3 & $\begin{array}{l}\text { Fitness value 30 because MP1 stands alone is not } \\
\text { subject to condition }\end{array}$ \\
\hline MP2 & 30 & 30 & MP1 & $\begin{array}{l}\text { Fitness value 30 because MP2 stands alone is not } \\
\text { subject to condition }\end{array}$ \\
\hline MP3 & 30 & 30 & MP1 & $\begin{array}{l}\text { Fitness value 30 because MP2 stands alone is not } \\
\text { subject to condition }\end{array}$ \\
\hline MP4 & 30 & 30 & MP5 & $\begin{array}{l}\text { Fitness value 30 because MP3 stands alone is not } \\
\text { subject to condition }\end{array}$ \\
\hline MP4 & 0 & 0 & MP7 & $\begin{array}{l}\text { Fitness value 30 because MP4 stands alone is not } \\
\text { subject to condition }\end{array}$ \\
\hline FrO & 30 & $\begin{array}{l}\text { Fitness value is small because there are the same MP } \\
\text { at the same time in different classes }\end{array}$ \\
\hline
\end{tabular}

From the weight of the results of fulfilling the above conditions, the fitness value is calculated using the following formula:

$$
\text { Fitness }=\frac{\text { Total weight in } 1 \text { day }}{\text { Number of hours in } 1 \text { day }}
$$

Following is the process of mutation and crossover saw from the smallest weight value as follows:

Table 6. Examples of mutation and crossover processes

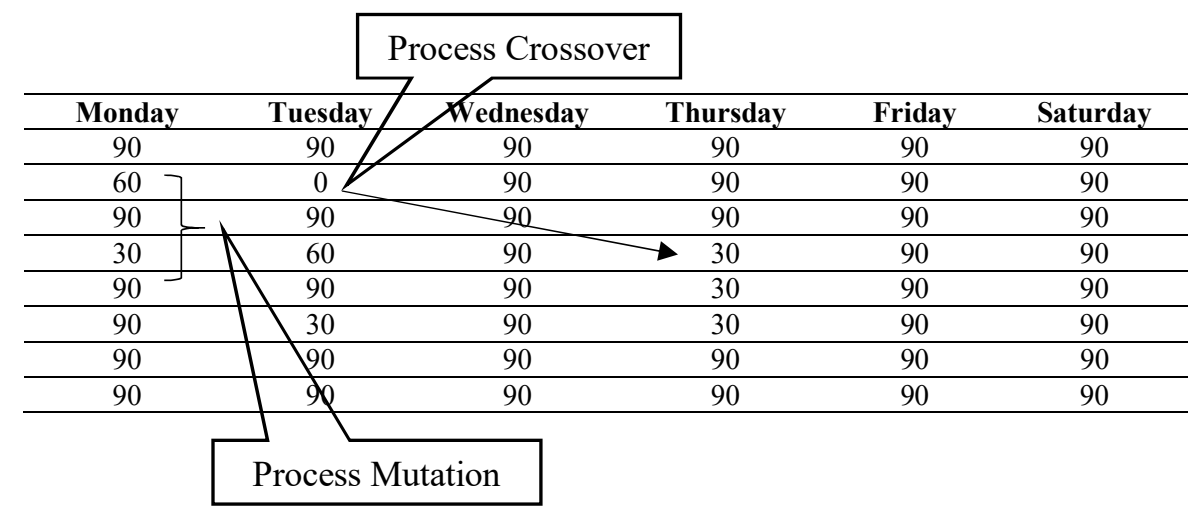

Calculate the most recent chromosome MSE with a chromosome that is the result of a crossover which is to calculate the average amount of all fitness on all chromosomes divided by the total value of the maximum amount of fitness. If the result exceeds the target error then the iteration continues, if the MSE error <target error then the iteration is stopped and as the final chromosome the genetic algorithm results.

129 | P a g e 


\subsubsection{Selection}

After calculating the fitness value, then the selection process is carried out which in this final project uses a ranking-based selection process.

1. The process of finding the smallest fitness value

The process of finding the smallest fitness value as a destination gene in one chromosome (in the crossover process) and as a destination gene on another chromosome (in the process of mutation).

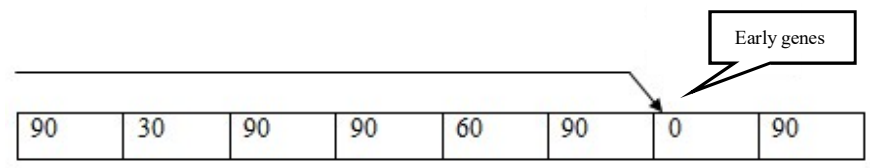

2. The process of finding other smallest fitness values

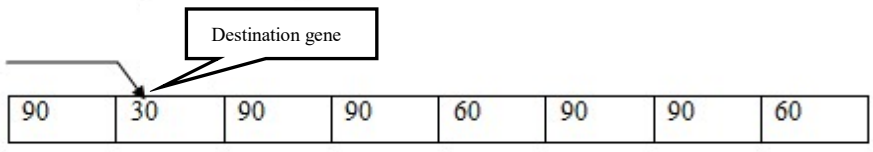

\subsubsection{Mutation}

After conducting the selection process, the mutation process is then performed, in which in this process the lowest fitness value in the chromosome is crossed with the gene that has the smallest fitness value in 1 chromosome.

1. The process of mutation from the first smallest fitness value to the second smallest fitness value

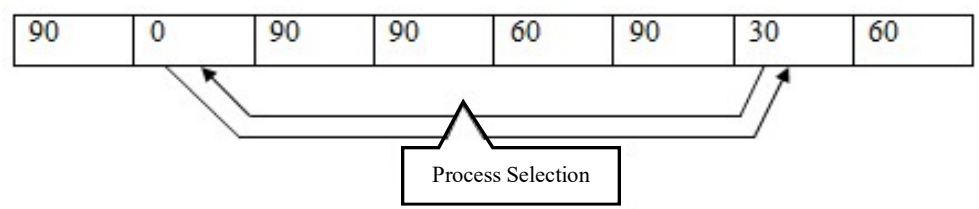

\subsubsection{Crossovers}

After doing the mutation process, then the process of crossing is carried out by transferring genes to other genes in 1 individual, wherein this process the lowest fitness value in the chromosome is crossed with the gene that has the smallest fitness value in 1 individual of the other chromosome

The process is considered complete if the average individual has maximum fitness value. If it is not maximized, the process is repeated from the determination of fitness to crossing until the average individual has the maximum fitness value or the iteration reaches the maximum limit.

\subsection{Scheduling Display Design}

This scheduling menu page will display a form containing input and button to process the making of the schedule using genetic algorithms.

$130 \mid \mathrm{P}$ a g e 


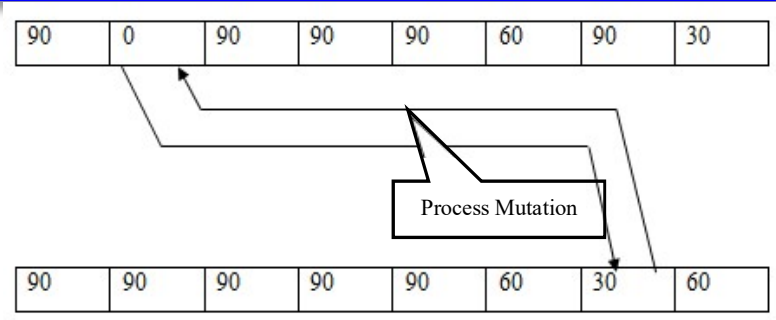

The following is a display of the scheduling menu display design on the subject editor page. It will display an input form that functions for the editor either saving, changing, or deleting subject data.

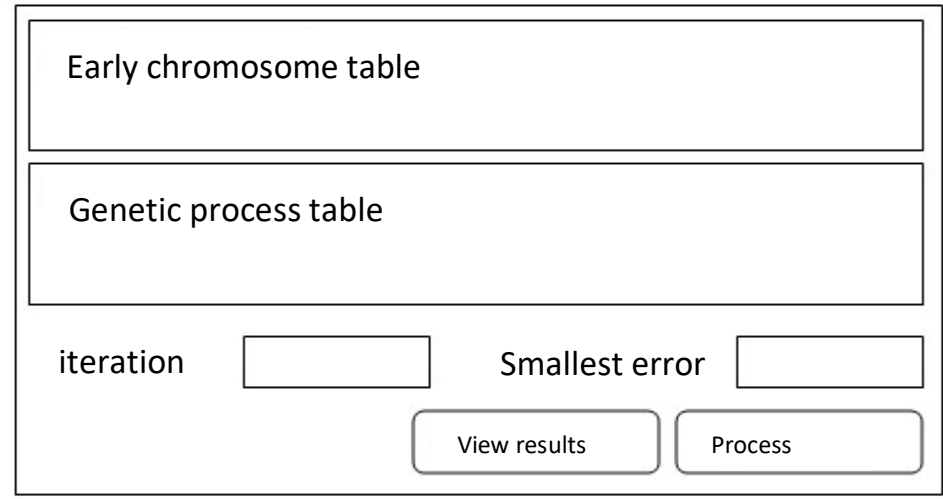

Fig.1. The design of the scheduling display

Testing system Optimization of subject scheduling at State Vocational High School 1 Malang, using genetic algorithms. Thus the user can find out about the successes and deficiencies that exist in the system or software that has been made in this final project.

\section{Implementation and Testing}

\subsection{Program Implementation}

The application that has been made consists of several classes that are interrelated with one another. Below is a display of the login form interface and the main menu that is useful for inputting teacher data, subject data, class data, and hours in the program. Here is the picture of the form mentioned above:

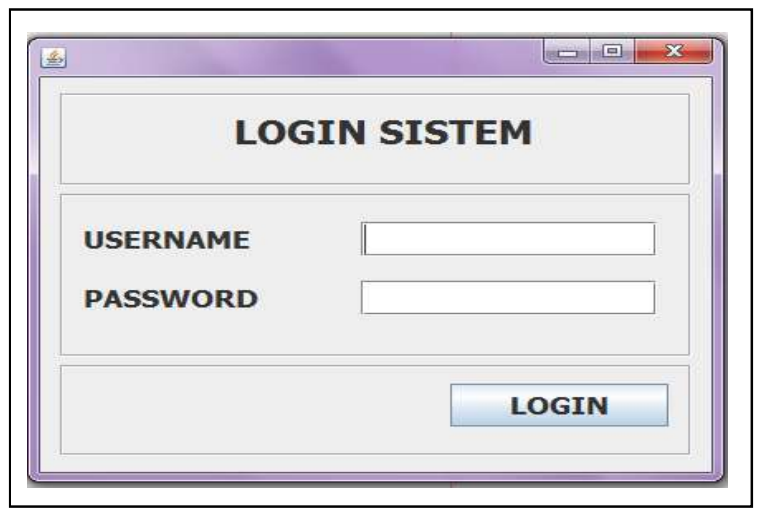

Fig.2. Log In Form

131 | P a g e 
JEEMECS (Journal of Electrical Engineering, Mechatronic and Computer Science) ISSN 2614-4859 Vol. 3, No. 2, August 2020, pp. 125-134 doi https://doi.org/10.26905/jeemecs.v3i2.4346

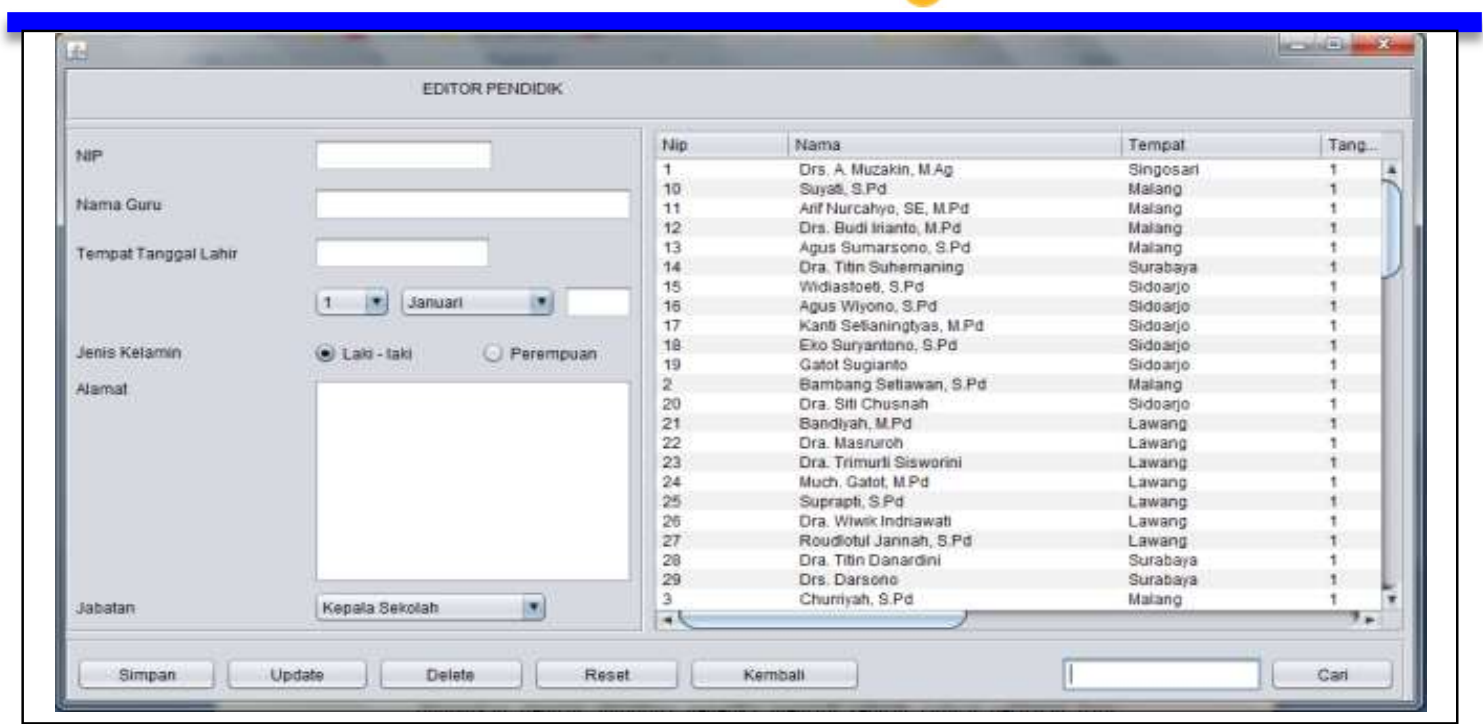

Fig.3. Add teacher data Form

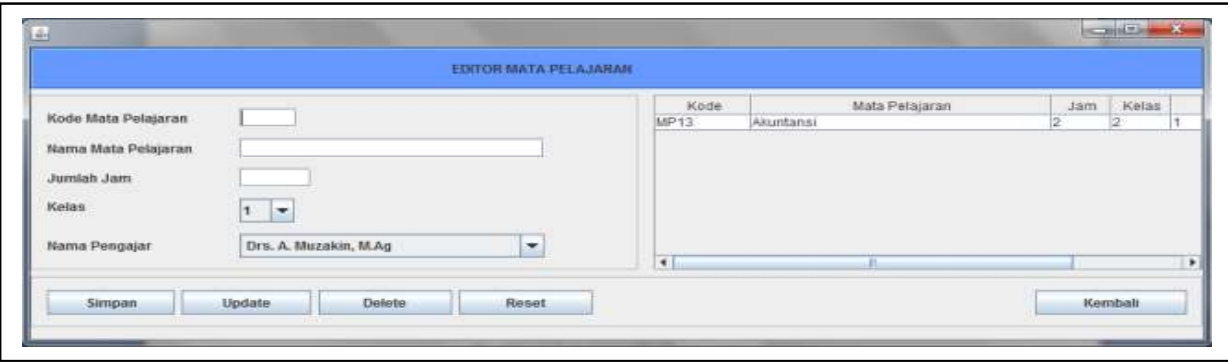

Fig.4. Data add subjects Form

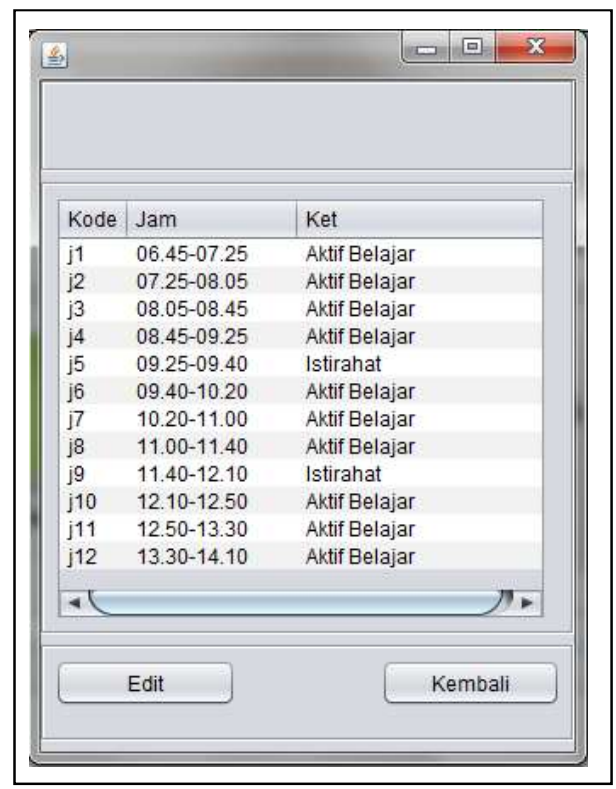

Fig.5. Clock form

The following form is used to display the process and results of creating subject schedules using genetic algorithms.

132 | P a g e 


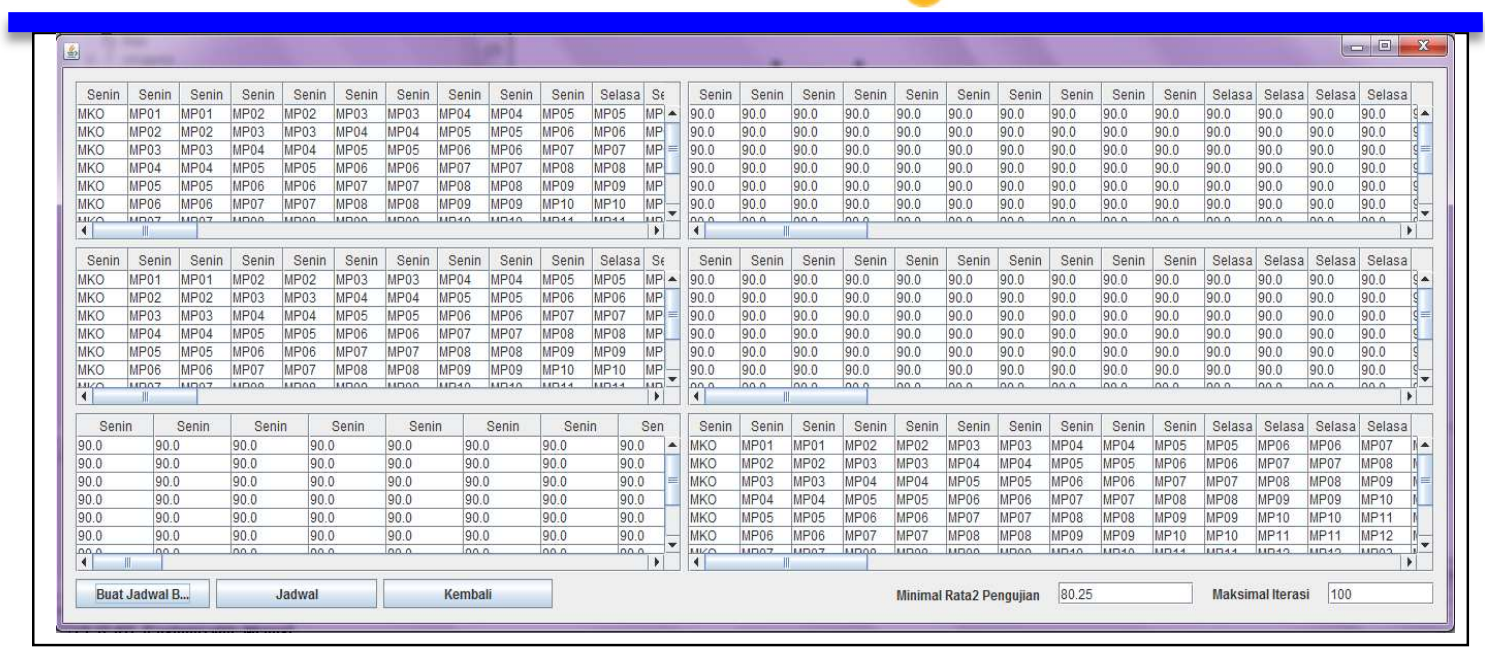

Fig.6. Application Form

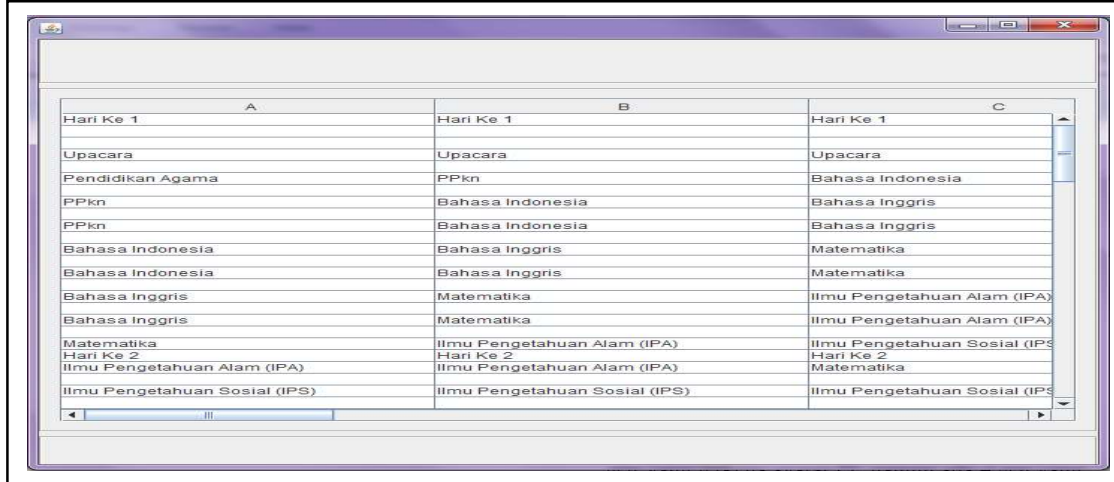

Fig.7. Display the results form

\subsection{Testing Stage}

The testing phase is carried out to find out which programs are made able to run well or not and to find out the shortcomings of the programs that have been made. This test is carried out to determine the difference in the number of generations needed if the termination condition in the form of the average fitness value of each chromosome gene is by the specified amount. The test results are shown in table 7.

Table 7. Tests carried out

\begin{tabular}{cccccc}
\hline F1 & F2 & F3 & $\begin{array}{c}\text { Average } \\
\text { fitness value } \\
\text { stops }\end{array}$ & $\begin{array}{c}\text { Fitness } \\
\text { value }\end{array}$ & $\begin{array}{l}\text { Total } \\
\text { Generation }\end{array}$ \\
\hline 35 & 8 & 152 & 80.25 & $80.25 / 90$ & 1 \\
\hline 84 & 8 & 140 & 80.5 & $80.50 / 90$ & 51275 \\
\hline 102 & 4 & 137 & 80.55 & $80.55 / 90$ & 141006 \\
\hline 97 & 4 & 142 & 80.65 & $80.65 / 90$ & 1486985 \\
\hline
\end{tabular}

Information :

$\mathrm{F} 1=$ The grace period of teaching a teacher in 1 day and 1 class

$\mathrm{F} 2=$ the number of teachers teaching more than 3 hours in 1 day and 1 class

$\mathrm{F} 3=$ there is a conflict between teaching the teacher and the other class 
From test 1 above, it can be seen that there are 35 genes affected by F1 conditions, 8 genes affected by F2 conditions and 152 genes affected by F3 conditions. Then the application stops when the new iteration runs 1 time with an average fitness value of 80.25 .

From test 2 above it can be seen that there are 84 genes affected by F1 conditions, 8 genes affected by F2 conditions, and 140 genes affected by F3 conditions. Then the application stops when the iteration runs 51275 times with an average fitness value of 80.50 .

From the 3 tests above, it can be seen that there are 102 genes affected by F1 conditions, 4 genes affected by F2 conditions, and 137 genes affected by F3 conditions. Then the application stops when the iteration runs 141006 times with an average fitness value of 80.55 .

From test 5 above it can be seen that there are 97 genes affected by F1 conditions, 4 genes affected by F2 conditions, and 1142 genes affected by F3 conditions. Then the application stops when the iteration runs 1486985 times with an average fitness value of 80.65 .

\section{Conclusions}

From the design and construction of application scheduling subjects with genetic algorithms in SMK 01 Malang that have been made it can be concluded that:

1. This application has fulfilled all the designs that have been made namely the scheduling application of subjects to be made, the process of division of teaching assignments is done outside the system. The system is only intended to arrange the schedule of subjects.

2. This application cannot be developed massively because it does not meet $100 \%$ output results it can be seen from the test results from the last test, it can be seen that the application stops when the maximum iteration is 1486985 with an average fitness value of 80.65 . And will produce the output: $89.61 \%$

\section{References}

[1] Pradnyana, Nanda Bagus, Dwi Sunaryono, Abdul Munif. 2012. Designing and Making Lecture Scheduling Applications Using Genetic Algorithms and Java API for XML Web Service Technology on the Android Platform. Surabaya: Sepuluh November Technology Institute (ITS).

[2] Mirwan, Muhammad. 2013. Optimization of District Level Government Coordination in Kota Bangun District of Kutai Kartanegara Regency. Samarinda: Fisip Unmul.

[3] Sutojo, T, Edy Mulyanto, Dr. Vincent Suhartono. 2011. Artificial Intelligence. Yogyakarta: Andi.

[4] Informatics. 2013. Genetic Algorithms. (http://informatika.web.id/algor algorithm-genetik.htm accessed on April 11 at 21.31)

[5] Yuliani. 2010.Genetic Algorithm to Solve Problems with Optimization of Constrained Functions by Encoding Round Numbers. Surabaya:Department of Information Technology Adisutjipto College of Technology (STTA).

[6] Cholis, Muhammad Nur. 2012.Applications for Moving Class Scheduling with Genetic Algorithms (Case Study of State Junior High School 1 Paiton). Malang: Informatics engineering department, Faculty of engineering, University of Muhammadiyah Malang.

[7] Pradnyana, Nanda Bagus, Dwi Sunaryono, Abdul Munif. 2012. Design and Manufacture of Application Scheduling Lectures Using Genetic Algorithms and Java API for XML Web Service Technology on the Android Platform. Surabaya: Sepuluh November Technology Institute (ITS). 